\title{
A VESSEL OF SINS FULL OF VIRTUES: THE IDEAL IMAGE OF THE FEMALE IN THE OCCASIONAL WRITINGS OF THE GRAND DUCHY OF LITHUANIA IN THE LATE SIXTEENTH AND EARLY SEVENTEENTH CENTURIES
}

\author{
JOLITA SARCEVIČIENE்
}

ABSTRACT. In this study the main attention is paid to the virtues of the ideal female image in occasional literature of the Grand Duchy of Lithuania. In the analysis of the wife's place in the family, her relations with her husband and children, her place in the religious community and her behaviour in the face of death, the author discusses the main social roles of the noblewoman as obedient wife, devoted mother, pious churchgoer and generous patron of the poor. Attention is also paid to training for these social roles and how they are described in the sources. The issues raised in the paper are investigated against the general background of European Christian culture.

In 1615 Nicholas Breton wrote:

A quiet woman is like a still wind, which neither chills the body nor blows dust in the face. Her patience is a virtue that wins the heart of love, and her wisdom makes her will well worthy regard. She fears God and flieth sin, showeth kindness and loveth peace. Her tongue is tied to discretion, and her heart is the harbour of goodness. She is comfort of calamity and in prosperity a companion, a physician in sickness and a musician in help. Her ways are the walk toward heaven, and her guide is the grace of the Almighty. She is her husband's down-bed, where his heart lies at rest, and her children's glass in the notes of her grace; her servants' honour in the keeping of her house, and her neighbours' example in the notes of a good nature. She scorns fortune and loves virtue, and out of thrift gathereth charity. She is a turtle in her love, a lamb in her meekness, a saint in her heart, and an angel in her soul. In sum, she is a jewel unprizeable and her joy unspeakable, a comfort in nature uncomparable, and a wife in the world unmatchable. ${ }^{1}$

${ }^{1}$ The Cultural Identity of Seventeenth-Century Woman (London - New York, 1994), p. 98. 
In these words one English writer of religious and pastoral works succinctly but precisely expressed the ideal female image, her social role and the main features of her character.

Although Christianity offered the same moral code and hope of salvation to men and women alike, it was commonly considered that woman was morally weaker by nature. Consequently she was more liable to vices than a man, and therefore only certain virtues were required of her. A comparison of sets of virtues, considered peculiar to men and women, shows that dynamic virtues were pronounced fit for men, and passive ones for women. Courage, magnanimity and domination were treated as male features, while modesty, submissiveness and self-denial were female traits. Contemporaries clearly distinguished between male and female models of behaviour as depending on their respective differing natures. It went without saying that male and female virtues were different, and it would have been not only unjust but also godless to ignore them. ${ }^{2}$

In the analysis of the ideal female image, recorded in the occasional writings of the Grand Duchy of Lithuania in the late sixteenth and early seventeenth centuries, an attempt is made to determine private and social spheres where a woman was treated as an example to be followed, her social role, the patterns of her character and way of life to be imitated, and what factors formed the norms and values conditioning her social significance.

The choice of occasional writings as a research source was not accidental. This is literature that encompasses panegyrics, didactic treatises and documentary sources. The authors instruct and/or give advice on how to behave and how an individual should seek the ideal, and propose normative suggestions, which might prove useful in various situations in one's life. It is a very significant part of public life, exhibiting certain social practices, the system of values, moral norms, etc. Occasional writings record the ideal model of the woman in the GDL, which at the same time is an expression of the collective consciousness of that period. The ideal model of the woman, presented in it, allows the reconstruction of the female image, formed in the understanding of the social élite. The main aim of this model was to offer society an example worth imitation, which in the period under investigation had to perform two func-

${ }^{2}$ Ibid., p. 96. 
tions. Firstly, it had to construct a set of female social roles, and secondly, that example had to acquaint the woman with social obligations facing her and consequently, teach her to tackle them.

In this paper female education and instilling the norms of ethical life are presented in the model of the ideal woman. Doubtless, the reconstructed models, the set of values and other rules and norms, recommended for the noblewoman, would not be acceptable in all social strata. The models analysed here are oriented towards a woman who belonged to the social élite. Almost all the famous families might be found among those to whose daughters and wives the corresponding writings were dedicated, in the words of one writer of such works 'the entire flower of the GDL' - the Chodkiewiczes, Kiszkas, Pacs, Radziwiłłs, Sapiegas, Słuszkas, Tyszkiewiczes, Wołłowiczes, Zawiszas, Zienowiczes, etc.

In all, 399 occasional writings were found, and 155 among them contained information about women. However, only a part of the nearly 400 works has survived, and only 291 of them were analyzed de visu. Furthermore, not all of them contained relevant information. The majority of the writings used in this study were funeral sermons, both in prose and in verse, in Latin and in Polish (121 pieces). The second largest group is epithalamia (60 items). There were other writings too, such as those composed on the occasion of the birth of a child. Nevertheless, sometimes they contain very interesting information.

Occasional writings were chosen for the reconstruction of the ideal type of the female also due to their normativeness, one of the principal features of this type of sources, which conditioned the presentation of the universal behaviour of the individual and fixed a kind of hierarchy of values, meant for certain strata of society. Occasional writings contain much biographical information, adapted the creation of the example to be followed. The method of persuasion of the pastoral mission, appealing to the practical experience of the social perceiver, conditioned the fact that occasional works became a document of the contemporary spiritual culture and a mirror of the social mentality with nearly all its components. The right to produce fiction and the duty of the moralizing poet required the idealization of the characters, so that they could be presented to society as standards of behaviour. ${ }^{3}$ In her investigation of the

3 A. Nowicka-Jeżowa, Sarmaci i śmierć (Warsaw, 1992), pp. 44, 74. 
Latin funeral poetry of the Vilnius Academy in the late sixteenth century, Rasa Jurgelenaite stressed that self-expression was not the aim of rhetoric genre. The reader was the most important object for the author of the occasional work. Meanwhile the contact between the rhetorical text and the reader was ensured by the nature of signs of such poetry; its essence was a certain code system, familiar to both the author and the reader. Of course, the public's preliminary attitude had also to be taken into account. ${ }^{4}$

Was the woman considered the recipient of these works? An affirmative answer is suggested by the very fact that the work itself was often dedicated to her. It is also noteworthy that the same editions (or parts of the same edition) were published both in Polish and in Latin. In the first place this is true of the epithalamia, which had different dedications: in Latin for the bridegroom and in Polish for the bride. There were differences in the content of the separate parts, too. In our opinion, the authors selected a particular language in order to be better understood and more favourably received by the recipients: the females, having received only domestic education, did not know Latin, therefore they had to be addressed in Polish.

In his/her life each individual had to perform several social roles, which could be treated as sort of constituent parts of the imaginary portrait; their sum would allow a reconstruction of the ideal model of the woman. Such a noblewoman would not be met with in GDL society in the sixteenth and seventeenth centuries, although possibly a more or less similar one might. Therefore the reader should not conceive the reconstructed type as an empirical average. It is to be hoped a priori that the model, constructed on the basis of socially acknowledged values and of the instruction of social behaviour, approximately corresponds to the model which existed in the contemporary understanding of the majority of the social élite.

In addition to information about her origin, relations with her husband, children and other relatives, patronage, participation in religious communities and sometimes in public life, and preparation for the death, occasional writings often presented a general charac-

${ }^{4}$ R. Jurgelènaitè, Lotyniškoji laidotuviu poezija. XVI a. pabaigos Vilniaus akademijos tekstu retorinè analize (Vilnius, 1998), pp. 95-96. 
teristic of the contemporary woman furnishing important data about the stereotype of the character and behaviour of an ideal woman. A symbolic human ideal had been closely associated with the idea of noble birth since antiquity. Noble origin often was a substitute for any panegyric and respectively an ante ipsum tope, as it was commonly believed that a noble is endowed with 'pure' virtues of body and soul by birth, which he/she later realized in life. ${ }^{5}$ In our sources origin is juxtaposed with moral life, customs worthy of imitation and winning the favour of people and God. Noblesse de sang was considered a solid basis for the formation of other positive features. The authors argued that virtues and nobility were acquired through blood ties and mother's milk. ${ }^{6}$ For instance, Jan Oziembłowski characterized Iohanna Petronella Eudoxia Kamieńska (née Zawisza) in the epithalamium on the occasion of her marriage in 1647 as a personification of the virtues of the families of Zawisza and Tyszkiewicz and in particular of her mother. ${ }^{7}$

Alina Nowicka-Jeżowa maintained that

The deliberations about a virtue, true, not an abstract, but a concrete one, and at the same time really noble, which 'imbibes strength in the customs of the people, are worthy of a philosopher'. The idea of presenting virtue through the prism of people's customs in literary terms is realized by the use of individualized laudatory constructions or by the praise of certain selected virtues. The eulogy is constructed according to patterns established for the presentation of 'well-born and honourable people' in poetry and corresponds to the axiology of Renaissance society ... The social ethics of funeral laudations cover the value of life, expressed in social terms, and measure it by the position and activities of the deceased rather than by the level of his spiritual life and irreproachability. ${ }^{8}$

Such visual and literary expression of the values, existing in the social consciousness, can be detected in various collections of

5 Ibid., p. 73.

${ }^{6}$ Sz. Okolski, Fundament przeciw fundamentowi. Duchowny przeciw światowemu. Na obseqviach JO Xiężny na Birżach y Dubinkach, naywyższey Podkomorzyney W. X. Lit. etc. X. Januszowej Radziwitłowej a z urodzenia swego Katarzyny z Potoka Potockiey Woiewodzianki Bracławskiey etc. (Lwów, 1643), A4v.

7 J. Oziembłowski, IWPIMP Iohannie Petronelle Eudoxiey Zawiszance, kasztellance Witepskiey, etc. złotego pierścienia ślubnego z herbu Tyszkiewiczowskiego y Zawiszanskiego winszuie ... (Vilnius, 1647)

${ }^{8}$ Nowicka-Jeżowa, Sarmaći $i$ śmierć, p. 78. 
emblems. How did the contemporaries view morality? Presenting Morality, Cesare Ripa ${ }^{9}$ stated:

[Morality] never gets old, on the contrary, all the time it gets stronger and more vital, because its actions became conditioned by the person's habits, acquired in life ... [It] is the most wonderful ornament of the soul ... Morality tends to shy away from the everydayness of public life in order to shine for the most moral people, about which Virgil wrote as lifted to the stars by the noble flight of morality ... [Morality] is always full of strength and does not yield to any enemy. ${ }^{10}$

The text indicates that the conception of morality in the sixteenth and seventeenth centuries was greatly influenced by Aristotle, who held that it was a property acquired by practice, i.e., learning, and allowed certain valuable activities. ${ }^{11}$ The authors accentuate female virtues - diligence, patience, wisdom, tenderness, obedience and chastity and introduce the readers to such symbolic biblical figures as Rachel, Ruth, Rebecca, Abigail, Judith and Esther as examples worth following for women.

However, all the biblical figures were only a part of the entirety, which the contemporaries saw embodied in Virgin Mary:

Some godly and reverend men of the Church have gathered this, that there were five women of great virtue of the [Mosaic] Law, the first five letters of whose names do make her [Mary's] whole name [Maria], to show that she had all their virtues wholly combined in her, as namely: Michal, Abigail, Rachel, Judith, and Anna. She is faithful to her husband as Michal, who saved her husband, David, from the fury of Saul, although he were her father and her king, nor preferring her own life before the safety of her husband. She was as wise as Abigail, who is highly commended for her wisdom: amiable in the sight of her husband as Rachel; stout and magnanimous in the time of trouble as Judith; patient

${ }^{9}$ C. Ripa (c.1560-1625) the Italian author of the classical collection of the emblems of modern Iconologia. The first edition of this book (without illustrations) appeared in 1593, the second, illustrated in 1603. In it the author presented a comprehensive catalogue of the visual forms of the symbolic culture. In our case, this work was used as an authentic specimen of the contemporary mentality in the verbal display of values, existing merely in the consciousness. Together with other publications on emblematics, this book was used in the Academy of Vilnius in the sixteenth and seventeenth centuries. For more detail, see D. Pociūtè, $X V I-$ XVII a. protestantu bažnytinès giesmès. Lietuvos Didžioji Kunigaikštystè ir Prūsu Lietuva (Vilnius, 1995), p. 98.

${ }^{10}$ C. Ripa, Ikonologia (Cracow, 1998), p. 234.

11 A. Anzenbacher, Etikos ¿̇vadas (Vilnius, 1998), p. 132. 
and zealous in prayer as Anna. Seeing then, that by this one name so many virtues are called to remembrance, I think it meet that good names be given to all women, that they might call to mind the virtues of those women whose names they bear; but especially above all other moral virtues, let women be persuaded by this discourse to embrace chastity, without which we are mere beasts and no women. ${ }^{12}$

The authors expressed the social wish to see in a woman, merely because of her sex, a patron and guardian of the poor, deprived and orphaned children. Society also wished the woman would follow the Virgin Mary as an example for her life. The urge to follow that example was noticed by other cultural researchers. Thus, basing himself on Albert Stanisław Radziwiłł's discourse, ${ }^{13}$ Vytautas Kavolis wrote:

Mary is an intermediary between the human being and God. The function of the female principle is often conceived similarly: the woman is an intermediary between nature and culture, she raises children, born as beings of nature and introduces them to the cultural sphere ... In Radziwiłł's text, the principal distinction is drawn between the male principle, creative, decisive and strong, and the female form, endowed with the mediatory function and conceived as an outward representation rather than an autonomous being. The female form represents the content, introduced by the male principle, it does not create anything on its own, and its being and gender are predetermined. The female element does not radiate its own content, it is merely prepared to represent the essence, conditioned by the male element ... Nevertheless, the rhetoric used byRadziwiłł in speaking about heavenly beings influences human behaviour as well. The deliberations about the Mother of God possibly could be projected onto the contemporary conception of separate male and female senses. I would suppose that in the Renaissance the male and female senses were perceived just in that way both in heavenly and earthly terms ... Such would be a conception of the perfect woman..${ }^{14}$

These arguments are supported by our sources, related to the image of the woman as an intermediary. She 'mediates' leading the

${ }^{12}$ Dorothy Leigh, The Mothers Blessing (1616); quoted in Cultural Identity, pp. 99-100.

13 A. St. Radziwiłł, Diskurs nabożny z kilku stow wzięty o wystawieniu naświętszey Panny ... Mariey przez Albrychta Stanisława Radziwitła, kanclerza W. $X$. L., napisany y wydany (Vilnius, 1633). Radziwiłł dedicated his work to his sister Krystyna Eufemia Radziwiłł, the abbess of the Benedictine convent in Nieśwież.

${ }^{14}$ V. Kavolis, Vyrai ir moterys lietuviu kultūroje (Vilnius, 1992), p. 42. 
children to God - acquainting them with the first truths of faith, teaching them prayers and ethical assumptions of Christianity. At the same time, she acts as an intermediary between human beings and nature - she is presented (though less frequently) as a healer. She is also an intermediary between people of different social status (between her spouse and his subjects) and of different age (teaching children the norms of morality and introducing them to society).

The writers discuss a certain 'set' of virtues, characteristic of an exemplary woman, like Aristotle does, who, following Socrates, stated that moral virtues go together: one cannot have one virtue without having them all. ${ }^{15}$ We must agree with this statement if we take into account that neither Aristotle nor the authors of occasional writings spoke about the reality in which absolute cases of virtues are not met with, but about the ideal and the aim. In their turn, each virtue could find its expression in concrete actions or attitudes of women. The analysis of the texts suggests that the character of a virtuous woman was in one way or another associated with self-denial: children are treated as a sacrifice to the Church and motherland, while her efforts, time and money are spent to support the poor. Even avoidance of the second marriage is presented as honourable intention to disassociate oneself from mundane concerns. The analysis of the set of virtues discloses the principal social roles of their possessor. In the latter half of the sixteenth and the first half of the seventeenth centuries the élite woman of the GDL is a pious daughter of the Church of the 'true' faith, a devoted wife and mother, a house-keeper of exemplary diligence and morality and a generous supporter of the poor.

'The concept of morality opens us a vista of the norm of moral life, which ultimately relates to the entire human life ... It is not separate actions that are important, but how one becomes good by oneself and one lives a good life" ${ }^{\prime 16}$ (emphases in the original). The woman is urged to be pious, submissive, enduring and to realize these traits in practice by honourable actions. In his speech on the occasion of the anniversary of the death (1639) of Tekla Radziwiłt (née Wołłowicz), Baltazar Stanisław Przyłuski stressed that the deceased never complained about her fate, she was satisfied that she

15 J. L. Ackrill, Aristotelis (Vilnius, 1994), p. 209.

${ }^{16}$ Anzenbacher, Etikos ivadas, p. 113. 
had been born a woman and did not mind that some men thanked God for having created them male. ${ }^{17}$ Idleness seemed to her a grave sin, she took great care of her husband, was temperate in eating, drinking and choosing her clothes, and in her will she expressed her wish to be buried with modest ceremony dressed in a Franciscan habit. ${ }^{18}$ This virtuous noblewoman did her best caring for the Church and religious fraternities.

All the virtues, attributed to a woman in occasional writings, can be divided into three groups, which define her attitude to and place in the family and society and are related to her virtuous behaviour (marriage), diligence (house-keeping), piety (church) and her social activities. Virtues formed the basis for the construction of the model of the woman's life, her relation with the husband, children and the Church. The sources, to which the authors resorted presenting the group of female virtues, were the authorities of the period: the Scriptures, establishing the norms because of its divine authority, the Church Fathers, charismatic personalities, considered competent in the sphere of morality, contemporary writings, didactic texts, the works on the betterment of society, various writings for women, containing a brief description of virtues. A publication of a slightly later date (1694) can serve as a specimen, presenting female virtues:

Meekness can be ranked with humility, and both of them are very comely and adorning to birth and beauty, commanding love and affection from all ... Meekness is not only enjoined to all as a Christian value but it is in a more peculiar manner enjoined to women as one main accomplishment of their sex ... Silence: the true virtue of silence cannot be too much commended. It is such a quality that I want words to express its worth ... Speech enricheth and corrupteth, but silence is poor, but honest. I am not so much against discourse as vain prattling, which consumes time and profiteth nobody ... Patience is a necessary exercise for everyone that lives in this world, for there is none so free from one cross or other but this virtue will be wanting to render him the more easy in the course of his life. The female sex especially ought to be endued with it, because they have frequent occasion to use it. ${ }^{19}$

${ }^{17}$ B. St. Przyłuski, Jako Rachel JOJMPP Tekla Woltowiczowna na Olyce y Nieświeżu xiężna JOJMPP Aleksandra Ludwika Radziwitta ... matżonka. Na rocznicy (Lublin, 1639), B3v.

${ }^{18}$ Ibid., A4v, B2.

19 [N. H.], The Ladies Dictionary (1694); quoted from Cultural Identity, p. 105. 
Did the authors rely on the knowledge acquired in their philosophical studies? Moral virtues were attributed to the sphere of moral philosophy or ethics. Here the main authority was Aristotle, whose ethical ideas had to become familiar to the future authors of occasional writings in their studies of philosophy, since ethics was one of its constituent parts. It was Aristotle who proclaimed that virtues are acquired by ethical training: 'Thus the virtues of our character appear neither by nature nor against nature, we are only able to acquire them, and subsequently we elaborate them by exercise. Besides, the inborn matters are attained at the start only as a possibility, while later we realize them in our activities .... ${ }^{20}$

In this manner the authors of occasional writings participated in the construction of the social role and its grounding. In addition to presenting concrete episodes of women's life, the authors showed ways of realizing the ideal life model, i.e., they taught the social role. Therefore the presentation and identification of the virtue can be called the first stage in the construction and education of the social role. To paraphrase Alasdair MacIntyre's idea, 'the list of virtues, presented in Ethics is not based on Aristotle's personal choice and estimate. It reflects what in the Greek society of his day Aristotle considered as 'the nobleman's code'21 Thus, it can be stated that occasional writings reflected the attitudes of contemporary society towards female morals. To conform to the framework of that norm is the principal aim of the woman. Conceived as a vessel of vices and temptations, a being weak by nature, she does her duty to those around her by taming her weakness.

The Polish historian Andrzej Wyrobisz holds that a noble family fulfils its main tasks, i.e., procreates and educates offspring, and performs economic, political and social functions; it also propagates historic traditions of the family and of the nation. ${ }^{22}$ That the family is valued as a duty to the kin and society is attested by a source. In his panegyric, published in 1598, Andrius Volanas praised Mikolaj Krzysztof Radziwiłł‘s marriage:

... you have decided to marry and to enter into the holy union of matrimony so that possessing such wealth and the age-old reputation of your

${ }^{20}$ Aristotelis, Nikomacho etika. Rinktiniai raštai (Vilnius, 1990), pp. 84-85.

${ }^{21}$ A. MacIntyre, Trumpa etikos istorija (Vilnius, 2000), p. 73.

${ }^{22}$ A. Wyrobysz, 'Patterns of the Family and Woman in Old Poland', Acta Poloniae Historica, t. 71, 1995. 
forefathers you could have children and educating them by your ducal endeavours would lead them to virtue and piety. As your spouse you chose a most illustrious and virtuous maiden from the family of dukes Wiśniowiecki, famous for their virtues, and in particular for their military distinction and glorious deeds. Her customs and female virtues attest to her amiable companionship. She bore you sons and daughters and endued them with noble qualities; the eyes of your children radiate their agile mind and intellectual education, and we are sure that the honesty, intelligence and piety of your children will be of enormous benefit to the state in future. ${ }^{23}$

Marriage and family life was valued by the contemporaries as a warrant of lasting traditions and transmission of values. The nobility inherited their identity from titular and famous forefathers and considered it their duty to pass it over to future generations. In his work on European nobility between 1400 and 1800, J. Dewald accentuates that marriage arrangements were not an easy task, which the élite of society associated with the establishment of useful ties by matrimonial union. ${ }^{24}$ That is evident in occasional writings, which in the first place deal with the noble birth rather than the character of the person under consideration. In the treatise, dedicated to the king of Poland's daughter Jadwiga, it is stated that

the union of souls, mutual love, friendship, fellowship and the most intimate ties are among parents and children, spouses, brothers, sisters, relatives, sisters- and brothers-in-law and one's people. In the absence of women there would be neither marriages, nor blood relations, nor relations-in law, and at the same time no love, no soul communion, and no close ties. ${ }^{25}$

Nevertheless, soberly arranged marriages of convenience excluded the possibility of amiable feelings between the partners. The situation was complicated by the contemporary way of life, when the spouses rarely stayed together. Service to the sovereign, military expeditions and visitations of estates awaited the husband. The wife lived a more unperturbed life. Nevertheless, soon after her

${ }^{23}$ A. Volanas, 'Panegirika šviesiajam valdovui ponui Mikalojui Kristupui Radvilai ...' Rinktiniai raštai (Vilnius, 1996), p. 270.

${ }^{24}$ J. Dewald, The European Nobility 1400-1800 (Cambridge, 1996), pp. 168 169.

${ }^{25}$ J. Ireneus Frederius, Apologia pro sexu foemineo. Versa per Joan Broscium. (Frankfurt, Brubach, 1544), B3. 
wedding day she had to tackle administrative problems on the estates placed at her disposal on her own, or, as the writers indicate, instructed by her husband in detail through letters or advisors. ${ }^{26}$ The social consciousness of the sixteenth and seventeenth centuries was still dominated by a stubborn belief that a man and a woman are different by nature, their tasks are different, and therefore they should be assigned different norms of morality: 'the way of a virtuous life is different for a man and a woman. ${ }^{27}$

Did society expect any emotional ties between the spouses? Judging from the source at our disposal, the answer should be positive. However, it is difficult to characterize these ties in modern terms. Christian love was a virtue recommended for the spouses and was believed to make a person righteous, wise, energetic and temperate. Such views as the highest ideals of Christian love were based on St Paul's teaching and were supported by St Augustine. This kind of love was characterized by St Paul as tender and patient, generous and averse to open recognition, modest, amiable and disliking falsehood, it 'endures everything, believes in everything, never loses hope .... ${ }^{28}$

The expression of love between the spouses is demonstrated by the care for each other in the case of illness or distress, common offspring, common occupations, etc. In his speech, published in 1646, Mikołaj Laurinowicz eulogized a generous foundation of the deceased palatine of Nowogródek, Tomasz Sapiega, to the church of Olszany (Alšènai) and gave high praise to of his wife Zuzana née Chrebtowicz, who together with her husband 'built God's house', ${ }^{29}$ i.e., their common interests witness the concord in the family. In the opinion of some authors, the woman's fate was predetermined in her creation - to be a helper and companion:

Let the wives know that they are created as helpmates for their husbands and are [meant] for husbands ... Since they are created not from the head, ... that they would not be commanding, neither are they from the legs, in order not to be underestimated by the husbands, but from the middle,

${ }^{26}$ Dewald, The European Nobility, p. 170; U. Augustyniak, 'Dwory kobiece i dziecięce w Wielkim Księstwie Litewskim w XVII wieku'. Mówiq wieki, no. 4, 1995, pp. 11-14.

27 Sz. Okolski, Fundament przeciw fundamentowi. A4.

${ }^{28}$ W. Pałubicki, J. Iluk, Matżeństwo i rodzina $w$ dawnym judaizmie i starożytnym chrześcijaństwie (Gdańsk, 1995), p. 154.

${ }^{29}$ M. Laurinowicz, Dom madrości, na pogrzebie JWPJMP Tomasza Sapiehy woiewody Nowogrodzkiego etc. w Olszanach (Vilnius, 1646), C3. 
moderately, neither as a mistress, nor as a servant, but in the middle, which means that they are companions. ${ }^{30}$

Thus in many works the wife and husband are seen as partners in the first place, while the feelings overwhelming them are referred to as friendship, and the spouse a friend, etc. Wawryniec Kollosowicz also spoke about the spiritual ties between the spouses in the epithalamium, written on the occasion of the marriage of Karol Jerzy Kroszyński and the daughter of the prefect of Kupiškis Elżbieta Tyzenhauz, in which he presented friendship as the noblest feeling between the spouses:

It is only friendship that fills and warms the people's hearts with wonderful, plentiful and comforting joys that not only sorrows and worries disappear but for some unknown reasons all pleasures acquire charm and beauty. Without friendship the highest power would be unpleasant and unappealing, and with it the greatest misfortunes and disasters would not be terrible. Without it paradise would not be paradise, still less would the world be the world. Friendship is God's creation, the first gift among all blessings. It is an ornament of happiness, a support in misfortune and a solace in suffering. Happy is he who is adorned by a clever friend. Happy on the earth is the couple, enjoying a common nobility by birth, a common set of virtues, one will, one wish and one understanding. ${ }^{31}$

In the period under review friendship was treated as a feeling, higher and nobler, and of longer duration than a quickly passing love. Confer Ripa's characteristics of Friendship and Tamed Love:

Aristotle says that friendship is a mutual, clear and common benevolence, encouraged and displayed by virtue and reason between people with similar moods and tempers ... due to spiritual openness, true love can far surpass all kinds of inventions and false embellishments ... a true friend, be he near or far, always loves us heart and soul. Even if times and fortune change, he is always ready to live and die for the sake of his friend.... friendship, established in blissful times must continue all the time and in need it must be stronger than ever; ... Time and poverty tame love best ... time weakens all passions of the human soul, in particular, love, the fragile aim of which lies hidden in the desire to enjoy the loved beauty,

30 J. Mrowiński, Stadło matżeńskie ż grona ziarniek stowa bożego y z autorów zacznych krótko zebrane ... (Cracow, Łazarz, 1561); Biblioteka pisarzów polskich, t. 4 (Cracow, 1890), p. 20.

${ }^{31}$ L. Kołłosowicz, Gratulatio nuptiarum inter perillustr. ac mm. d. d. Carolum Georgium a Kroszyno Kroszynscium et preillustr. ac magn. d. d. Vilhelmia Tizenhauzen, capitanei Kupiscensis filia, die 21 Januarii anno 1652. Wierz do Alszki Elżb. Tyzenhausowny starosczanki Kupiskiey (Vilnius, 1652). F. 
which is but skin-deep, and when it fades in time, love must be replaced by other feelings. Time is a tamer of love, which finally turns into a pity for the time wasted on its trivialities ... a fatigued and bald lover, weary and poor, having wasted all his resources on love affairs, becomes a prey of misfortune, hunger and misery. ${ }^{32}$

Thus, the author is liable to identify true love with friendship and to treat love itself as a feeling, which emaciates and soon passes away. Philippe Ariès, however, emphasized that love occupied a very important place in the consciousness of seventeenth-century society by involving an individual more inextricably than other social ties. $^{33}$

It is noteworthy that only the friendship between men was considered to be worth particular respect. The contemporaries were not liable to agree that equally perfect emotions could tie a man and a woman. The female soul was treated as less noble, feebler and unable to maintain strong and steady contacts. The relationship with the woman could be established in two ways - through love and through marriage (not treated as coherent notions!). Love was a burning, sudden, unstable flame, which was extinguished by friendship. Meanwhile, marriage was not contracted for the sake of friendship. Nevertheless, the contemporaries managed to perceive, at least theoretically, there was a basis for a friendship between a man and a woman. 'If such an unrestricted and free contact were established, in which not only the souls could derive complete satisfaction, but also the bodies were in such cohesion that the human would be totally involved, such friendship, doubtless, would prove still stronger and more dignified' ${ }^{34}$ Thus, friendship between the spouses looks more like a desirable ideal in occasional writings.

People of that age understood that family life was not always a bed of roses: '.. after all, spouses rarely live in concord'. ${ }^{35}$ Ripa even proposed to portray Marriage as a youth with a burden on his back and his feet in fetters, because

${ }^{32}$ Ripa, Ikonologia, pp. 147-148, 97.

${ }^{33} \mathrm{Ph}$. Ariès, Historia dzieciństwa: dziecko i rodzina $w$ dawnych czasach (Gdańsk, 1995), p. 203.

${ }^{34}$ Historia życia prywatnego, t. 3. Od Renesansu do Oświecenia (Wrocław, 1999), p. 479.

${ }^{35} \mathrm{U}$. J. Pielecki, Wschód nieśmiertelniey slawy po zachodzie żywota y wielkiey nadzei IWWP Hieronima Chodkiewicza starosty Mozyrskiego. Przy żałobnym akcie WJWPP Isabelli Lackiey Chodkiewicziwey opisany przez ... (Vilnius, 1650). G. 
... marriage is a heavy burden and an obstacle to a man's freedom of action, it is selling oneself out and surrendering to the rule of the eternal law. Nevertheless, there is something valuable and, in many cases, desirable in marriage, the more so that it ensures the human beings descendants and lawful inheritors of their honour, fame and esteem, deserved by them in the state. Therefore, [the humans] take that burden on themselves for the upkeep of the state, and at the same time for the experience of the pleasures of sanctioned love ... ${ }^{36}$

The authors of occasional writings tended to speak about such marriages, in which both spouses sought the same aim, were attentive and considered each other's opinion. Nonetheless, they were not equal partners. The father and husband dominated in the family, and their authority was evident in all social layers. It was maintained that male superiority was determined by nature itself.

In the first place, the innate power [of the husband] over [his] wife is conditioned by natural law, indicating that a nobler, stronger and more resolute counterpart should have control over the more submissive, weaker and less gifted one. The same is prescribed by divine law, conferring the right of the husband over his wife. Finally, these attitudes are consistent with human law, both custom law and written records. Thus, one must control one's wife and love her, too. That must be the power of love and honour, a power over an equal being - the friend of one's bed and life, pure-minded, careful and devoted to the affairs of her spouse, children and home; if she fails to perform her duties, that can often be the fault of her spouse. ${ }^{37}$

The Polish cultural historian Maria Bogucka noted that in the works of the period under consideration writers often demonstrated a critical attitude and even hatred towards women, and that Western European emancipation, brought by the Renaissance, actually had not yet reached the society of the Two Nations. ${ }^{38}$

The woman was considered a member of the family, and that determined the division of roles and spheres of influence of the spouses. The principal concerns of the wife were the children, the comfort and welfare of her husband and the everyday management of the household. These were the directives given to the woman concerning the relations to her husband by a famous moralist of

${ }^{36}$ Ripa, Ikonologia, p. 265.

${ }^{37}$ L. Opaliński, ‘O powstaniu społeczności ludzkich'. Filozofia i myśl społeczna XVII wieku, part I (Warsaw, 1979), p. 217.

${ }^{38}$ M. Bogucka, 'The Foundations of the Old Polish World: Patriarchalism and the Family', Acta Poloniae Historica, t. LXIX, 1994, p. 38. 
that period Bartłomej Paprocki: to have as few thoughts of her own in her head as possible and to learn everything from her husband, to take care of the house and never reproach her husband; to be faithful to him, not to dress up; not to have any secrets from him. True, this misogynist's ideas should be approached cautiously - his own marriage with a well-to-do widow was unlucky. Being no more able to bear her character and heavy hand he fled the home and returned only after her death. ${ }^{39}$. Thus, it can be stated that his 'wisdom' was merely a subjective moralizing of a husband, whose marriage was unhappy. Nevertheless, Paprocki's views were popular in society and remained topical for quite a long time - that is attested by the five editions of his work in 1587, 1629 and 1697 (the dates of the first and third editions are unknown). ${ }^{40}$

The husband's responsibility towards his wife is permanently accentuated. 'A man, taking care of his wife, must treat her as his equal, neither giving her strict orders as if she were a servant, nor requiring of her service, fright and full dependence as if from a captive'. ${ }^{41}$ The wife's submission and devotion to her husband must spring up not from fear, but from her love to him and her understanding of his superiority.

On the other hand, society gave the woman a chance to advise her spouse, doubtless, on condition that his male authority was not abused. One of the first Polish authors on matrimonial life, Jan Mrowiński, stated in his treatise, published in Warsaw in 1561, that although it was not shameful for a husband to take his wife's advice, that would mean acting contrary to both divine and human law. Therefore a woman herself had to understand what she risked in teaching her husband. When a wise woman saw that her husband was at fault, she could advise him quietly and respectfully. One of the first to speak publicly about the unjust male attitude to the weakness of the female nature was the French writer Christine de Pisan. In her Livre de la Cité des Dames, composed in 1405, she argued that it was in no way possible to require anything from one's husband in an angry manner. 'If you speak strictly to him, you will not achieve anything, even if he took you along a wrong path, you would experience only pain. He can even leave you, and peo-

39 Polski stownik biograficzny, t. 25/104, 1980, p. 178.

${ }^{40}$ K. Estreicher, Bibliografia Polska, t. 24 (Cracow, 1912), pp. 60-61.

${ }^{41} \mathrm{~F}$. de Avila, Excitarz duszny abo przestrogi chrzesciańskie dla życia $w$ każdym stanie (Cracow, Lobaczewski, 1608), p. 91. 
ple will make fun of you. That would incur you greater shame and dishonour than would your silence', ${ }^{42}$ The Carmelite monk Mikołaj Kmita warned both men and women that they should be aware of their duties: 'In matrimony remember who is the head: the head of the wife is the husband. He is the head in the same manner as the wife is the tail; the head is to rule and the tail is to be submissive ..., since when somebody occupies somebody else's place, the result is disorder'. ${ }^{43}$

In contemporary opinion, the choice of a wife determined a man's future life. Considerable attention was given to this issue in a book on education, one of the first original books written on this subject by local authors in the middle of the sixteenth century. ${ }^{44}$ It was maintained that in order to raise good descendants it is necessary to choose one's wife carefully and to treat her properly. Piety, modesty and sufficient wealth were essential features of a future wife. ${ }^{45}$ Mrowiński wrote that '[when looking for a wife] pay attention to God's word and love rather than possessions or wealth, choose a woman and not clothing, a friend and not a master, take a companion and not a dowry ....' ${ }^{46}$ Mikołaj Rej, whose Postilla was published by Jokūbas Morkūnas in Vilnius, was negative about marriage based on feelings, and recommended searching for a kindhearted, pious and well-mannered woman of the same social standing, who could also provide support with her dowry. ${ }^{47}$ His ideal was a marriage based on mutual respect: 'And if you want your wife to be faithful to you, modest, serious and honest in everything, you must also be the same to her, show her how to behave and do not set a bad example to her'. ${ }^{48}$

${ }^{42}$ B. S. Anderson, J. P, Zinsser, A History of their Own: Women in Europe from Prehistory to the Present, vol. 1 (New York, 1989), p. 350.

${ }^{43}$ M. Kmita, Trzy matki urodzeniem, pobożnościa, potomstwem ozdobione a kazaniami pogrzebnymi koronie Polskiey y familiiom ku ozdobie, potomnym czasom do podziwenia y naśliadowania wystawione y podane przrz ... (Cracow, Szedel, 1639), p. 14.

${ }^{44}$ Its author, Erazm Gliczner (1533-1603), a Lutheran by faith, worked as a tutor of the dukes Jerzy, Jan Szymon and Aleksander in the Olelkaitis estate of Slutsk for several years in the middle of the century and again between 1558 and 1559; see I. Lukšaitè, Reformacija Lietuvos Didžiojoje Kunigaikštystèje ir Mažojoje Lietuvoje. XVI a. trečias dešimtmetis - XVII a. pirmas dešimtmetis (Vilnius, 1999), p. 250.

${ }^{45}$ E. Gliczner, Ksiażki o wychowaniu dzieci (Cracow, 1976), pp. 7, 129, 132-137.

46 J. Mrowiński, Stadło matżeńskie (Cracow, Łazarz, 1561), p. 18.

${ }^{47}$ M. Rej, Zwierciadto (Cracow, 1905), pp. 106-111.

${ }^{48}$ Ibid., p. 117. 
One gets a very contradictory picture about the imaginary woman's place in the matrimony. The sources present a model of emotionally stable matrimonial ties, in which the partners are attentive to and take care of each other. Sometimes such relations are referred to as intellectual partnership, understood as mutual attention and emotional ties, without, however, ignoring the superiority of the husband. ${ }^{49}$ The type of inter-spouse relations, which could be called 'submissive partnership', characteristic of the patriarchal family, was propagated universally, where friendship was considered the most sublime and profound feeling between the spouses. Such marriage was usually based on a clear division of activities: the husband's sphere was external affairs of the family (and possibly of the entire kin), while the wife was concerned with the household. In such a family the wife might seem discriminated, but her position was significantly strengthened by the birth of children and her exceptional right to educate them. The ideal image of the wife possibly was grounded in her experience of the everyday life, and that was the decisive factor in shaping her role, which she had learnt watching her parents' family.

People were greatly interested in the continuation of the human race. Ripa wrote about fertility as about 'the greatest happiness of every married woman, since being fertile she bears fruits, so desirable in matrimony ... What is more excellent and splendid than children?'. ${ }^{50}$ They were treated as the possibility to continue the traditions and values of the family and society. Historical scholarship supports the opinion that in that period the woman's role was concentrated mainly in marriage and motherhood, which meant not so much giving birth to the children as their proper physical and spiritual care and education in the early stage of their life. Talcot Parsons maintained that in the division of the roles in the family the role of the woman was concentrated in motherhood, the essence of which was the amalgamation of care and love, which for the child was a kind of identification object in the earliest period of life and later a basis for a successful social entrance. Meanwhile the father's role was primarily the performance of economic, political and other functions rather than the socialization of his children. The socialization of the individuals was treated by Parsons as the con-

49 E. Aronson, M. T. Wilson, R. M. Akert, Psychologia spoleczna. Serce $i$ umyst (Poznań, 1995), pp. 429-434, 438-439.

50 Ripa, Ikonologia, p. 133. 
ception of duty and competence, necessary for adult life. The conception of the duty consisted of two parts: the acceptance of the dominating system of values of a particular society and the adaptation to perform a certain social role. The preparation the child for the latter process was the mother's task. ${ }^{51}$ The woman was expected to be an active participant in the formation of her children's character. She was their first teacher, formulating prohibitions and rules and introducing them into the world of the accepted social norms. ${ }^{52}$ The woman's right to educate good Christians, members of society, and future mothers was significant enough to pay attention to the requirements to mothers that they could endue young people with principles and patterns of behaviour. The most intensive socialization of children and, at the same time, the teaching of their social roles take place in the early stage of their development - in that period the mother pays particular attention to her children, and that means that she is the main mentor of their social roles. In other words, society enables the woman to take part in the process of acculturation.

Two other important aspects of the child's socialization are the education of piety and high standards of morality. Since the mother herself was taught such subjects from her young days, the demands and expectations of society were quite real, and she could be an example. Occasional writings do not contain any other perceptible model of the mother. Constructing her relationship with the husband and the children on the basis of her spiritual and moral virtues, the mother fulfilled the social requirements. She passed her best qualities to her children through her exemplary behaviour, and verbal teachings. Witnessing her relations with her husband, a woman's children subconsciously copied this model of family relations.

From the very beginning there existed a difference in the mother's relations with the daughters and with the sons. That could be related to the different social tasks of the sexes in future, in their turn conditioning different education and the passage of the elements of different roles. In 1619 Adam Rasius argued that

the education of sons and daughters should differ: the boys must be taught sciences and military matters, while the girls learn piety and house

${ }^{51}$ T. Parsons, Struktura spoleczna a osobowość (Warsaw, 1969), pp. 69, 134, $172,272,313 \mathrm{ff}$.

52 Bogucka, The Foundations, p. 42. 
keeping. This is connected with the following question: should girls shape their soul with liberal arts? Although I am aware that the attitude of many women is positive on this issue in our age, my answer, nevertheless, is negative. Firstly, God's word indicates that they should keep silent in church. Furthermore, by universal laws they are estranged from state management and other governmental duties and services. Why then should they be taught liberal arts? For a woman it is enough to know how to read, write and count in order to be able to learn God's law and to pray more devoutly.. .53

In 1651 the professor of the Academy of Vilnius Aaron Aleksander Olizarovius stressed that boys and girls should be taught equally faith, piety, obedience and chastity, and here the equality must end. All-round education is redundant for girls, and elementary knowledge of reading, writing and music is sufficient. It is best for them to engage in spinning and weaving, and the most important thing is chastity and a strictly limited communication with persons of the male sex. ${ }^{54}$ 'You have sons? Teach them and take care of them since infancy. You have daughters? Protect their bodies and do not show them a cheerful face' - such was a categorical assertion of European moralists. Thus, the socialization of boys was directed towards their future social life; and good housekeeping, modesty, innocence, avoidance of bad conduct and familiarity with household tasks were priorities in the education of girls. The writers urged parents to pay great attention to the morality of their daughters, to instil the fear of God and the esteem for parents in them, since that was the basis of everything. ${ }^{55}$ Girls had to prepare to become wives and mothers, knowing no indolence. The mother had to watch her daughters carefully, since being weak by nature they are always liable to justify themselves. ${ }^{56}$

The relationship between a mother and her sons was slightly more complex. Doubtless, in the early period of their life the boys communicated with their mother most intensively and received the principal truths of faith, etc., from her. Subsequently maternal influ-

53 A. Rasijus, 'Politikos ir teisès traktatas apie kilmingumą ir prekybą', Lietuvos mokykla ir pedagogine mintis XIII-XVII a. Comp. K. Grigas, V. Kryževičius and I. Lukšaitè (Vilnius, 1994), pp. 301-302.

${ }^{54}$ A. A. Olizarovijus, 'Trys knygos apie politinę žmonių visuomenę', Lietuvos mokykla ir pedagogine mintis XIII-XVII a., p. 339.

${ }^{55}$ A. J. Jędrski, Mąra Indzienigierska dwóch domów dla siebie albo Kazanie pokazane na pogrzebie Alexandry Radzimińskiej ... (Vilnius, 1652), C4.

${ }^{56}$ Rej, Zwierciadło, pp. 46-47. 
ence weakened considerably, and when the boys reached the age of nine or ten, they would fall under the influence of the father or any other adult male, so that he could 'pass' his power to them. The relationship between the mother and her sons was constructed differently, the main roles of the men being their involvement in society.

A mother's ability to educate sons as citizens was particularly valued. In his speech written in 1639 , Kmita praises mothers for their teaching their children to be useful not only to their family, but also to the Commonwealth and the Church. ${ }^{57}$ Mothers are often presented as active participators in the life of their sons, encouraging their studies and often achieving their maternal aim.

The task of the men of the social élite was to provide for their families, not to lose the favour of the sovereign, to obtain new positions and to increase the wealth of the family. The woman, staying at home, had 'to fetch three fortunes' - health (to take care of her husband and children), wealth (to see that her housekeeping was profitable) and peace. The image of an attentive and thrifty homemaker, tirelessly taking care of the family's welfare, goes back to the ideal woman of the Scriptures. One of the most valuable female virtues was diligence. Judging from occasional writings the woman's activity at home was valued as requiring time, understanding and patience. Probably even unconsciously the writers appreciated the woman's role at home, where her positions were particularly strong: she supported the morale of the servants, took care of the children and managed the whole household. She was relatively independent of her husband, who had no idea about various female jobs, and respectively did not interfere with them.

The most highly valued virtues of 'the lady of the house' were attentiveness, tenderness, benevolence, amicability, a good temper, the care of those surrounding her, the ability to understand and help them. Sometimes women showed their interest in the problems of their subjects. Thus, in his sermon on the occasion of death of Anna Ostrogska Marcin Hińcza noticed that in order to be accessible and help her subjects she travelled in her possessions. ${ }^{58}$ Many authors stated that pious and honest ladies of the manor would

57 Kmita, Trzy matki urodzeniem, p. 56.

58 M. Hińcza, Złota korona abo kazanie na pogrzebie IO xiężny Anny z Sztemberku Ostrogskiey, hrabiney na Tarnowie, woiewodziney Wolyńskiey (Cracow, Cesar, 1636). E2v. 
educate the women in the neighbourhood setting them an example; on their estates they kept a number of young ladies, trained them, looked for bridegrooms for them and gave them dowries. ${ }^{59}$

Nearly all occasional writings showed that many women were engaged in charity and that society accepted that as a positive activity. In that period the Church was one of the institutions of social life and, in contrast to other spheres of social activity, was open to women's initiative; outside the walls of the home charity was almost the only female occupation that was not criticized and received widespread approval. Faith was one of the important features of world outlook of contemporary people. Presenting a pious and charitable woman, active in her community's religious life, the authors did not consider themselves as discounting universally accepted attitudes, according to which a woman had to take care only of her home. Conversely, they presented society with one more aspect of an exemplary self-sacrificing woman. A woman could be useful to more than her own family. Being active in the church did not clash with the typically male interests in the service of the state, and the propagation of that activity did not raise any threat to the status quo of the patriarchal society. Therefore the picture of women as patrons of beggars, monks, priests and pious daughters of the Church, striving towards the spiritual ideal, is particularly vivid in our sources. Ways of participating in the community's religious life were varied - support of the poor (alms, charity meals, distribution of clothes, visiting and nursing the sick and other services), participation in the activity of various religious organizations, making pilgrimages to holy places famous for their miracles, in addition to attending church services, performing various ascetic practices, all kinds of foundations including collecting funds for churches and for the publishing of religious books.

Mercy was acknowledged as an inborn female quality:

Compassion and a Merciful Disposition, praiseworthy in the female sex: Compassion is that which inclines us to do good to all, but more especially to those that are in misery and stand in need of our help ... and this chiefly should reign in the loving tender breasts of the female sex, made for the seats of mercy and commiseration. They being made of the softest mould, ought to be most pliant and yielding to the impression of pity and compassion, and to redouble the horror of any sad object. ${ }^{60}$

59 Przyłuski, Jako Rachel JOJMPP Tekla Wołlowiczowna, B3-v.

${ }^{60}$ [N. H.] The Ladies Dictionary; quoted in The Cultural Identity, p. 105; emphasis in original. 
One of the most vivid and detailed portraits of a pious and charitable noblewoman - Anna Tyszkiewicz - was drawn by Raymund Zaianczkowski. She visited almshouses and prayed there, her daughters and she washed the feet of the inmates, kissed and fed them and gave them alms. Once the almshouse was visited by a beggar with a hideously deformed face, which was loathsome even to the servants. Tyszkiewicz herself put food into his mouth and gave him clothes. She and her daughters organized meals for the beggars of Słonim, served them themselves and ate together with the poor. ${ }^{61}$

Charitable activity varied in its scope. The image of the first wife of Jan Karol Chodkiewicz Zofia (née Mielecka) is unanimously formed on the basis of her rich foundations. She supported a college in Lwów, monasteries in Jaroslavl, Lublin, Nieśwież, the Jesuit church in Lublin, the churches of St Stephen, St John and St Casimir in Vilnius, a church and a monastery in Kretinga and a monastery of Augustinian friars in Bychów. ${ }^{62}$

Protestants paid greater attention to schools, preachers, book publication, all that considering of importance in the strengthening of their positions. However, due to the limited number of books available to Protestant women and due to the insignificance of the works of mercy for salvation in Protestant opinion, such information is rather fragmentary and does not lead to major conclusions. Occasional writings, unlike real situations, reflect mainly the attitudes of the Catholic élite to the piety of the woman.

A number of the researchers of this period note 'the Renaissance' of asceticism in the seventeenth century - ascetic practices came to be treated as a peculiar expression of serving God. Asceticism is also often referred to by Zaianczkowski. Thus, Anna Tyszkiewicz, waiting for her husband to return from the captivity in Moscow, lived in a nunnery, where she slept on the bare ground and prayed a lot, and she had separated her daughters from the male milieu; she herself,

suffering great pains in the conditions that emaciated her body and were most dangerous for her health, she saw the hope of her recovery in her

${ }^{61}$ R. Zaianczkowski, Morze od brzegu śmiertelnosci do portu odpocznienia WJMP Annę Kandzierzawska Tyszkiewicowa marszałkowa Stonimska prowadzace. Z łez WJMP Piotra Tyszkiewicza marszałka Słonimskiego matzonka ustawione, 1653, D-v.

${ }^{62}$ St. Rochowicz, Kazanie przy exequiach świętey pamięci JWWP Zofii z Mielca Chodkiewiczowej hrabini ze Szkłowa na Bychowie ... w Wilnie w kościele św. Katarzyny zakonic reguly św. Benedikta ... (Vilnius, Karcan). B4-v. 
sole doctor, Almighty God. She was overwhelmed by her love for God, her neighbours and enemies; before marriage she had longed to devote her life to God by becoming a nun. She was a member of the societies of the Holy Rosary, St. Anne, St Francis and of the Scapulars. She took pleasure from her talks with God while reading, and what she had learned she told others deductively. At night she used to sneak to church to pray; she walked barefoot, knelt on her bare knees and prayed so fervently that her hands, holding the prayer-book, did not feel any cold as they were warmed by the Holy Ghost during the biggest freezes. In her various pilgrimages, particularly to Żurowicze, she went barefoot, without any rest, and although she was such a noble lady she would lead a beggar or a sickly person by the hand and feed them; sometimes she crawled on her knees quite a long leg of her journey to a miraculous picture. And there, without any public solemnities and any grand-lady pride she, her pious daughters and servants recited a litany contritely before the Queen of Heaven. In winter she gave her own clothes to little naked beggars, taught them prayers and gave them everything that she had redundant in her clothing to cover their nakedness. ${ }^{63}$

Ascetic practices were probably more typical of women, whose morality concerned society greatly due to the universally acknowledged weakness of the female nature and submission to bodily wants. Therefore, a woman, whose body was conceived as a vessel of sins, was frequently an object of both clerical and lay criticisms. Kmita stated that Anna Lubomirska called her body an old donkey, which had to be tamed permanently by means of prayers, fasting and whipping. ${ }^{64}$ Ascetic practices were popular and practised not only by the laymen, who sometimes desecrated the expression of piety, but also in the monasteries. Thus, Barbara Kiszka (née Radziwiłł), although not a nun, spent seven years in a convent and observed all its rules and regulations: she got up early, ate the food served in the refectory, took care of the poor residing in there, and especially was concerned with one of them: she sent him food, sewed clothes, looked after him and covered the expenses of his burial. ${ }^{65}$ She flogged herself so often that she sometimes needed even medical help. It is difficult to say whether her health really

${ }^{63}$ Zaianczkowski, Morze do brzegu śmertelnosci, C4-v.

${ }^{64} \mathrm{Kmita}$, Trzy matki urodzeniem, p. 66.

65 A. Lawski, Pociecha duchowna JOX Annie z Kurlandu Radziwiłlowey marszałkowey wielkiey W. X. L. starościney Kowieńskiey etc. żałosny z śmierci WJMP Radziwilowny Kiszczyny, iedyney córki swoiey (Cracow, Lobaczewski, 1614), D4. 
deteriorated so markedly that her mother had to take her back from the convent. Such a decision could have been conditioned by the mother's wish to make her sole daughter a good match - after some time Barbara was married to Mikołaj Kiszka. ${ }^{66}$

It is noteworthy that ascetic practices were characteristic only of this section of contemporary society. The Reformation brought a possibility to search for another relation with God. Although the majority of the occasional writings deal with the Catholic attitudes, some information can be derived from them about the expression of Protestant piety. Was there a difference between the Catholic and Protestant views towards women? Given the change of the relationship with God, did attitudes to women change? What were the ideas of Martin Luther and John Calvin?

Researchers note the ambivalence in Luther's views towards women. In the beginning he was favourably disposed in relation to women and even encouraged their active participation in the reformation of the Church. Subsequently, with the spread of the movement, he disassociated himself from an active involvement of women. $\mathrm{He}$ argued that it did not befit a woman to preach sermons. Luther considered her a creature weaker both physically and spiritually, although as a believer she was more fervent as the man. Marriage ensured her a place defined by God, and child bearing was her mission. ${ }^{67}$

Calvin's views were affected by his communication with the most educated women of his time. He acknowledged that some exceptional women could govern, but female rule was against nature and it was God's punishment of men for their incompetence. However, that kind of power had to be tolerated because it was impossible to fight against such a female ruler. ${ }^{68}$ Luther and Calvin admitted that a woman must submit to a man, because such is God's will. Both women and men are equal before God. Nonetheless, in other respects there must be no doubt about female submissiveness. That was an outcome of their attitude to Eve, which cast aspersions to the entire female sex.

${ }^{66}$ Ibid., D4v.

${ }^{67}$ M. Bogucka, 'Reformacja i Kontrreformacja a pozycja kobiet u progu ery nowożytnej'. Kobieta i rodzina $w$ średniowieczu i na progu czasów nowożytnych (Toruń, 1998), p. 179.

${ }^{68}$ Ibid., pp. 180-181. 
Thus, the change in the faith did not result in the changes in the attitude towards women - it was a matter of deeper social manifestation of mentality rather than faith. True, there were partial changes in the manner of the display of women's piety - greater emphasis was placed on personal relationships with God. On the other hand, investigators noticed that the intimacy of the professions of faith gradually entered the life of Catholic women. In this way 'a new model of women's piety developed, offering a chance for a more intensive experience of the great dogmas of the Christian religion. Women ... endeavour to find some moments of solitude every day'. ${ }^{69}$

The Czech historian Jan Janaček has written that:

Religion was a sphere of genuine meditation freedom for gentry and town women and for rich women and poor. In moments of happiness and sorrow they addressed God directly and felt much freer doing that in the absence of their husbands and fathers. Faith strengthened their moral code, imbued their unquestionable virtues with sense and fanned the embers of their ambitions. It often grew into hysterics and fanaticism; more often it was shifted into the background in the face of the temptations of the transitory life, but it always brought relief in difficult situations and explained mystically the blows of circumstance, difficult to understand. ${ }^{70}$

Bogucka presents a continuation of these ideas:

It would be mistaken to account for the religious fervour of women merely by their more emotional character, without taking into consideration the fact that active participation in religious life offered women a certain sphere of freedom, gave them a chance to leave their homes and to put aside everyday duties and allowed to implement higher ambitions. In those centuries religion was the only sphere of public life in which there was place for women. ${ }^{71}$

The Church constantly reminded the faithful that nobody knows his last hour and that it is never too early to start preparing for it. By supporting the poor and the church, a woman not only earned their gratitude but also prepared her way to heaven. A woman striving towards the spiritual ideal in this sphere had a chance of realizing Christ's precept to the apostles: 'Sell that ye have, and give alms;

${ }^{69}$ Historia życia prywatnego, t. 3, p. 439.

70 J. Janaček, Białogłowny rozważnej żywot $w$ czasie burzliwym (Warsaw, 1982), p. 291.

${ }^{71}$ Bogucka, 'Reformacja i Kontrreformacja', p. 175. 
provide yourselves bags which wax not old, a treasure in the heavens that faileth not, where no thief approacheth, neither moth corrupteth. For where your treasure is, there will your heart be also'.72

European literature of the sixteenth and seventeenth centuries is characterized by the development of the mediaeval theory of 'the art of dying': numerous treatises on the ars moriendi indicate a crucial change in the conception of death compared with the Middle Ages. Death becomes an absolute metaphysical category, which can be defined by the metaphor of 'the separation of body from soul'. The meditation of death becomes an important aspect of life, because knowing how to die is understood as knowing how to live, in contrast to the preparation for death, elaborated in the Middle Ages, in the hope of salvation in extremis. Desiderius Erasmus of Rotterdam and many of his followers - the sixteenth-century reformers - accepted the Platonic definition of death, adapting it to the practical preparation for it. Preparation for death is identified with ethical life that acquaints a person with ontologically important values. Every instant the Renaissance individual was taught to be in a state, in which a dying person of the Middle Ages had to be. ${ }^{73}$

Thus, the spiritual treatises of the sixteenth and seventeenth centuries do not deal any more (at least not in the first place) with the preparation of the people for death, but about how to teach them to think about it. From now on death is a way of learning how to live better and more nobly. Catholics and Protestants sought their way to the Almighty differently in everyday prayer and on their deathbed. The Reformation rejected Catholic images of the afterlife and burial rituals and looked for a new relationship with death. However, that was not so simple. The encounter with death was entangled in such a web of various rites and customs that it was not so easy to eradicate them from the convictions even of those belonging to the élite. The Reformation made attempts to modify the images of the afterlife and salvation, but the norms, related to death, remained unchanged. Reconciliation with one's neighbours, the proof of genuine faith on one's deathbed, and the rules, defining the behaviour of the dying were considered 'good death' by the Protestants as well.

A French Calvinist and an Anglican preacher speak like a Roman Jesuit cardinal does. In the treatment of death the identity of views prevails in

${ }^{72}$ Luke, xii, 33-34.

${ }^{73}$ Pociūtè, XVI-XVII a. protestantu bažnytinès giesmès, p. 119. 
the élite of the Christian world. Even the most conservative Catholics, for whom the ideas of the mediaeval monks were still significant, are confident from now on that it is not the hour of death and not the physical death that define the real value of the life of any person and that they are crucial for the person's existence in the afterlife. ${ }^{74}$

The sermons delivered at burials and published afterwards were also important in the formation of the image of death. - For researchers they are a valuable source. For example, the sermon of the Lutheran Samuel Dambrowski on the death of Elżbieta Naruszewicz (née Nonhart), published in 1624, presented a conception of a good and bad death:

In this world people are different, $\ldots$ and they die differently. In their lives some people, when alive and healthy, pay little heed to God and are more interested in earthly than heavenly matters ... The end of such people is deplorable because ... they go to hell in the twinkling of an eye. Others gladly serve Lord God and always meditate upon Him while still healthy. Therefore, in illness as well keeping only Him in their hearts, they sincerely desire a short and happy end, if their last hour comes; they know that death is merely the gates to eternal life. O blessed are those who live and die in that way, because they rest after their toils, and their deeds follow them. Their souls are in the hands of God, and the pain of death will not touch them. ${ }^{75}$

A woman must distinguish herself in religious practices, receive the sacraments as often as possible and be ready to meet death in the Christian manner ... As an exemplary mother, relative and neighbour she must create fundamental life structures all her active life and protect the social ties of the Sarmatians, earning herself the epithets of the biblical heroines. The sign of her personal perfection ... is suffering. All these merits allow the Sarmatian woman to die feeling her virtue and peace. ${ }^{76}$

J. Tazbir also noted that 'the model of a substantially advanced ascetics is much more frequently found in sermons reviewing the life of matrons than men'. ${ }^{77}$

What does exemplary death look like? The Jesuit Wojciech Czarnocki described such a case in 1636. Anna Ostrogska (née

${ }^{74}$ F. Ariès. Chelovek pered litsom smerti (Moscow, 1992), p. 261-262.

75 S. Dambrowski. Desideria Christianorum albo pragnienia duchowne Chreściańskich ludzi nad zmartym ciałem zacnie urodzoney $i$ azlachetney PJMP Elżbiety Nonhartowny Naruszewiczowey ... (Vilnius, 1624), p. 1.

${ }^{76}$ A. Nowicka-Jeżowa, Homo viator - mundus - mors, t. 3 (Warsaw, 1988), p. 59.

77 J. Tazbir, 'Wzorce osobowe szlachty', Szlaki kultury polskiej (Warsaw, 1986), p. 41. 
Kopeć) fell ill during a church service. When she learned that she would not recover she said that she was not afraid of death. Then she received Holy Communion and the anointing of the sick. Thus she expressed her thanks to God that she was dying as a Catholic and did not let the crucifix out of her hands. Lastly she blessed her relatives and servants. For the last three hours she was unable to speak and indicated by glances and signs that she understood the prayers that were read. ${ }^{78}$

A good death is a sign of God's grace, a kind of remuneration for the good one has done to the Church and faith. Zofia, the wife of Jan Karol Chodkkiewicz, was thus richly rewarded. Jędrzej Grądzki described her last days in great detail in a speech upon her death. For a long time she and her husband had been taking care of the Bernadine monks of Kretinga, built a monastery and a church there. She spent her last days in Kretinga, where she had done so much for the good of faith. Having learned about her serious illness, Zofia herself decided to go to Kretinga. God willing, she did not die on her journey. Besides, her husband came in time, and she made her last will and asked him to take care for their daughter. Moreover, the day of her death was out of the ordinary. Zofia was hopelessly ill on Friday. Nevertheless, in the author's words, God willed that she die only on Saturday, the day of the Virgin Mary, when the priest was praying after Mass and Communion. ${ }^{79}$

On the occasion of the death of Anna Jadwiga Sapiega (née Woina), the Dominican monk Dominik Krasuski wrote that she was born in the palace of the Sapiegas in Warsaw, and she also died there at the age '... of thirty-odd years'. Before her death she saw the Virgin Mary, who held her little dead daughter Katarzyna by the hand and invited the mother to herself, too. ${ }^{80}$

Women met death quietly, relying on God's grace and mercy. Although death was not imagined without any greater or lesser

78 W. Czarnocki, Malogranat abo kazanie przy exequiax JOJMPP Anny z Sztemberku Xiężny Ostrogskiey, Hrabiney na Tarnowie, woiewodziniey Wołyńskiey (Cracow, Cezar, 1636), D2v-D3.

79 A. Grądzki, Kazanie na pogrzebie zacney pamięci JWJM Paniey Zophiey $z$ Mielca Chodkiewiczowey, woiewodziney Wileńskiey, hetmanowey anywyższey W. X. L. miane przez ...w kościele tegoż zakonu w Kretyndze 4 Juli r. p. 1619 (Vilnius, 1619), 12.

${ }^{80}$ D. Krasuski, Sakrament $w$ śmierci a śmierć $w$ Sakramencie na pogrzębie JWJM Paniey Anny Jadwigi Woynianki Mikołajowej Sapieżnej Woiewodziney Brzezkiey etc. (Warsaw, Trepliński, 1642) D2v. 
pains, physical and moral, the authors of occasional writings perceived suffering as incompatible with the image of the woman that they described. Therefore society was presented with a model of a woman who had lived a blameless life and died a peaceful death. The appearance of a new model of an honest, gentle and exemplary death was characterized by Ariès in the following way:

This model replaces the one which artes moriendi of the Middle Ages brought into the room of the dying, heavily laden with the struggle between the forces of heaven and hell, reminiscences of life and temptations of Satan. The new model of death is that of a believer, who does not take into consideration the moment of his physical death itself, but meditates intensively about his whole life. In such a death there is no place either for the excitement or dramatic performance that abound in the artes moriendi of the late Middle Ages. ${ }^{81}$

Having been taught all her life to be submissive, to serve the others, to be a patient and pious daughter of God, a woman finally attained the ideal propagated by the authors of occasional writings. Having reconciled herself with everyone and shaken off the thought of sin, which persecuted her throughout her life, she became the centre of events and faded away with a smile on her lips and a sincere heart. Idealized death, as presented in occasional writings, is a logical outcome of the idealized female life.

Thus, initially ars bene moriendi, and afterwards occasional writings shaped a death picture of a virtuous Christian woman full of unreal hopes, and in addition to it, a very fragile and vulnerable ideal. Raising the requirements, the clergy intensified the fear of death because many believers considered themselves unable to conform to the norms of the ideal and thus condemned themselves to eternal sufferings. Strange as it might seem, the ideal female image recorded in occasional writings can be viewed in the same way. High moral standards, constant self-control, attempts to please a spouse, devotion to children, household duties and setting an example to servants, instigation not to indulge into pleasures, obligations to care for the poor and the church, etc., produced troubles for women, permanently reminded about their light-mindedness, proclivity for sin and weakness of nature. Striving towards the spiritual ideal and taking less care for her people alienated her from her family. In contrast, concentrating her efforts on the family, she would no longer be able to seek salvation.

81 Ariès, Chelovek, p. 269. 
Our sources show that in the hundred-year period under consideration the established social attitudes towards women remained unchanged. It was only with the spread of literacy and the general cultural development in the Grand Duchy of Lithuania, and with the increase in the numbers of literate women, able to get acquainted with the offered pattern of life and system of norms, that more women started to take interest in those issues.

Concrete examples show that the virtues and values discussed and the universal models of behaviour inspired by them were not merely the production of the writers conditioned by the contemporary rules for occasional writings. Actually they functioned in reality and existed in the mindset of the people (at least of the educated ones) as social norms. The interrelationship between reality and normative models was mutual. During her lifetime a woman performed several social roles, some of which embraced all spheres of her activity (a virtuous, pious, caring female), while others were pertinent only to some periods of her life (a wife, a mother, a house-keeper). Performing these roles, she was useful to society and earned its recognition and respect. A proper performance of her roles ensured the sustenance of the contemporary type of social structure.

Research into the ideal model of the woman has revealed a number of factors that formed it, such as oral tradition, the teaching of the Scriptures and the Church Fathers and the rhetorical way of thinking. It can be maintained that the forms of Aristotelian thinking of the latter half of the sixteenth and the first half of the seventeenth centuries were particularly influential. Attitudes were also affected by moral philosophy and ethics as well as by the contemporary intellectual European and local writings. The authors of occasional writings also contributed to the formation of the female ideal, generalizing the aforementioned factors in their works and presenting the episodes of the life of the noblewomen of the GDL as examples. At the same time, the authors of occasional writings added their share in the construction of the social role, in its presentation to society and in teaching the exemplary models of female character, behaviour and virtues. The ideal female model had its beginning in the Christian tradition of European culture, incorporating the heritage of antiquity through the Christian reception of Aristotle.

Viewing the history of mentality in a wider context, one can see that in all the above-mentioned sources, a significant component of 
which was occasional writings, there are the so-called 'contents of thinking', encompassing universally accepted principal convictions, ideological and ethical conceptions of GDL culture. In this way, through the presentation of the ideal female model, society within the Grand Duchy of Lithuania was acquainted with European Christian culture.

\section{Author Details}

Jolita Sarcevičienè is a graduate of the University of Vilnius; in 2000 she defended her doctoral thesis on the ideal female model in the occasional writings in the GDL. At present Dr. Sarcevičiene is an assistant researcher at the Department of the History of the GDL of the Lithuanian Institute of History.

Address: LDK istorijos skyrius, Lietuvos istorijos institutas, Kražių 5, LT-2001 Vilnius, Lithuania

Email: sarcevia@takas.lt

\section{PILNAS DORYBIU NUODĖMIU INDAS: \\ IDEALUSIS MOTERS IVAIZDIS PROGINĖJE LDK LITERATŪROJE XVI a. ANTROJE P.-XVII a. PIRMOJE P.}

Santrauka

\section{JOLITA SARCEVIČIENE்}

Tyrimu šaltiniu pasirinkusi XVI a. II p.-XVII a. I. p. proginę LDK literatūrą, straipsnyje autorè supažindina su joje nusakytu idealiuoju moters ivaizdžiu, pagrindinị vaidmenį skirdama moteriškosioms dorybèms. Analizuodama žmonos vietą šeimoje, santykius su vyru ir vaikais, moters vietą religinèje bendruomenèje, elgseną mirties akivaizdoje, autorè aptaria ir pagrindinius moters-didikès socialinius vaidmenis: klusnios žmonos, atsidavusios motinos, pamaldžios bažnyčios duktès ir dosnios vargšu globėjos. Nemaža dèmesio straipsnyje skiriama šiu socialinių vaidmenu mokymui ir pristatymui naudotame šaltinyje. Iškeltus klausimus siekiama atskleisti bendrame krikščioniškosios Europos kultūros kontekste.

Received 05 April 2001 